\title{
Simulasi Numerik Prediksi Erosi Aliran Fasa Cair-Gas Berpasir Pada Belokan Pipa Sumur Minyak Mentah Menggunakan Model Finnie, McLaury dan Oka
}

\author{
H. J. Atmaja*, S. Kamal, Sugiyono \\ Departemen Teknik Mesin dan Industri, Fakultas Teknik, Universitas Gadjah Mada \\ Jalan Grafika No. 2, Yogyakarta 55281 Indonesia \\ E-mail: *jaya_77a@yahoo.com
}

\begin{abstract}
Abstrak
Keberadaan pasir dalam fluida produksi di industri perminyakan merupakan hal yang tak dapat dihindari. Pada kecepatan fluida tertentu, pasir berpotensi menimbulkan erosi pada dinding perpipaan yang apabila proses tersebut terjadi secara terus menerus maka dapat menyebabkan penipisan dinding pipa, mengurangi tekanan kerja maksimum fluida yang diijinkan, kegagalan pipa dan akhirnya fluida hidrokarbon keluar dari sistem tertutup pipa. Kondisi ini berpotensi menimbulkan kerugian dalam hal keselamatan kerja, kehilangan finansial dan isu lingkungan. Kompleksitas mekanisme erosi akibat fluida berpasir didalam perpipaan memerlukan bantuan perangkat lunak untuk menghitung besaran dan profil erosi didalam pipa. Makalah ini memprediksi laju erosi aliran multifasa cair-gas-padat pada belokan pipa yang didominasi fasa cair dengan CFD menggunakan ANSYS Fluent 18.2 dengan validasi berdasarkan eksperimen yang dilakukan peneliti lain yang sudah dipublikasi. Dari hasil simulasi, laju erosi dengan model Oka lebih mendekati hasil eksperimen dibandingkan model Finnie dan McLaury. Hal ini dimungkinkan karena kondisi eksperimen lebih sesuai dengan model erosi yang dibangun oleh Oka. Hasil simulasi lanjutan menunjukkan bahwa laju erosi pada pipa meningkat dengan kenaikan laju alir dari minyak mentah dan gas, ukuran partikel dan laju alir partikel. Laju erosi menurun dengan meningkatnya diameter pipa.
\end{abstract}

Kata kunci: Komputasi dinamika fluida, laju erosi maksimum, laju alir minyak mentah, laju alir gas, laju alirpartikel, ukuran partikel, diameter pipa.

\begin{abstract}
The sand presence in production fluid in oil and gas industry is unavoidable. At a certain fluid velocity, sand potentially causing erosion in the piping wall. If the process occurs continuously it can reduce pipe wall thickness, reducing the maximum allowable working pressure of the fluid, piping failure and hydrocarbon loss of containment. This condition will result in losses in terms of worker safety, financial and environmental issues. The complexity of the erosion mechanism due to sandy fluid in the piping system requires software to calculate the magnitude and pattern of erosion in the pipe. This study predicted the erosion rate of liquid dominated multiphase flow at pipe elbow by using CFD ANSYS Fluent 18.2 and validated based on published experimental studies conducted by other researcher. The simulation results show that
\end{abstract}


erosion rate of Oka model has the lowest relative difference with experimental result compared with Finnie and McLaury model. This may be caused by experimental condition that was more suitable with erosion model developed by Oka. Further simulation revealed that erosion rate at the pipe wall increased with increasing crude oil and gas flowrate, particle size and particle flowrate. Erosion rate decreased by increasing pipe diameter.

Keywords: Computational Fluid Dynamics (CFD), maximum erosion rate, crude oil flowrate, particle mass flowrate, particle size, pipe diameter.

\section{PENDAHULUAN}

Pengangkatan (lifting) minyak mentah dari reservoir ke permukaan, baik dengan aliran alami (natural flow) atau aliran dengan bantuan pompa atau gas yang diinjeksikan (artificial lift) memungkinkan material padatan selain minyak mentah (misalnya pasir) ikut terbawa. Material pasir atau padatan lain yang berasal dari reservoir ketika terbawa ke permukaan akan menimbulkan masalah pada proses pengolahan fluida dan peralatan penunjang produksi. Pasir dapat menimbulkan erosi, kebuntuan pipa dan korosi dibawah endapan pasir.

Pencegahan pasir untuk naik ke permukaan sebenarnya dapat dilakukan dengan menggunakan peralatan pekerjaan sumur (workover) atau perawatan sumur (well service) seperti pemasangan saringan pasir (sand screen) dan gravel pack didalam tubing annulus. Saringan pasir tidak mampu untuk menyaring partikel kurang dari $50 \mu \mathrm{m}$ untuk tidak terbawa aliran fluida ke permukaan. Begitu pula gravel pack lebih efektif untuk mencegah material padat yang kasar atau berukuran tertentu saja, sedangkan material yang lebih kecil atau halus masih bisa melewati peralatan tersebut (Parsi et al, 2014).

Selain itu, pencegahan material padatan dari reservoir ke permukaan berpotensi menimbulkan masalah lain yang lebih besar yaitu terkumpulnya material padat tersebut di reservoir atau tubing produksi yang justru akan menghambat aliran fluida itu sendiri. Untuk itu penanganan pasir pada fluida produksi bergeser dari upaya untuk pencegahan (prevention) menjadi pengelolaan (management). Artinya pasir dengan ukuran tertentu diperkenankan untuk naik ke permukaan bersama fluida produksi, tetapi dikelola dengan cara-cara tertentu di permukaan.

Keberadaan pasir dalam fluida produksi sudah menjadi hal yang umum ditemukan pada proses produksi minyak mentah. Properti pasir pada kecepatan aliran fluida yang rendah sangat rentan terhadap pengendapan (sedimentasi) yang dapat menyebabkan hambatan pada aliran fluida, meningkatkan jatuh tekanan (pressure drop) dan mempercepat proses terjadinya korosi pada dinding dalam pipa terutama pada bagian yang tertutupi oleh pasir tersebut. Sementara pada kecepatan fluida yang tinggi, adanya pasir berpotensi menimbulkan erosi yang apabila proses tersebut terjadi secara terus menerus maka dapat menyebabkan penipisan dinding pipa, mengurangi tekanan kerja maksimum fluida yang diijinkan, kegagalan pipa dan akhirnya fluida hidrokarbon keluar dari sistem tertutup pipa. Kondisi ini akan berpotensi menimbulkan kerugian dalam hal keselamatan pekerja, kehilangan finansial dan isu lingkungan.

Studi erosi pada sistem perpipaan sudah intensif dilakukan para peneliti sejak lebih dari lima dekade tetapi kebanyakan penelitian berfokus pada aliran multifasa gas-cair-padat dengan fasa dominan adalah gas (Edwards et al, 2001; Humphrey, 1990; Salama, 2000), sementara masih sangat sedikit yang melakukan penelitian baik berbasis eksperimen maupun komputasi dinamika fluida (CFD) pada aliran slurry yang didominasi oleh fasa cair. 
Dalam studi ini dianalisa pengaruh beberapa parameter aliran gas-cair-padat (slurry) yang didominasi fasa cair terhadap potensi terjadinya erosi pada sistem perpipaan sumur migas hususnya pada belokan pipa. Simulasi dilakukan dengan menggunakan software komputasi dinamika fluida ANSYS Fluent 18.2 untuk memprediksi erosi dan memahami secara lebih mendalam parameter-parameter yang mempengaruhi laju erosi.

\section{SIMULASI NUMERIK}

Simulasi pada studi ini menggunakan software ANSYS Fluent 18.2. Pada bagian ini akan dibahas secara lebih rinci geometri komputasi yang digunakan, mesh dan model multifasa yang dipilih.

\subsection{Domain Komputasi}

Simulasi numerik pada studi ini dilakukan untuk mensimulasikan laju erosi akibat pasir pada aliran multifasa cair-gas dengan geometri seperti ditunjukkan pada Gambar 1. Geometri adalah pipa vertikal dengan belokan keluaran arah horizontal. Diameter pipa adalah 50,8 mm dengan radius curvature 1,5 kali diameter. Panjang pipa sebelum dan setelah belokan masing masing adalah 42 dan 3 kali diameter.

Untuk mendapatkan mesh terstruktur maka prosedur diterapkan dengan membagi geometri menjadi beberapa bagian seperti ditunjukkan pada Gambar 1. Penampang pipa dibagi menjadi lima luasan, dibentuk dari persegi dengan pusat yang sama dengan lingkaran dan garis terdekat yang menghubungkan sudut persegi dengan lingkaran (Fluent 6.0 User's Guide, 2001). Panjang persegi adalah X dan panjang garis hubung adalah Y. Rasio X dan Y adalah 2. Tabel 1 menunjukkan studi kualitas mesh dengan memvariasikan X dan Y. Sesuai dengan tujuan simulasi maka mesh divalidasi dengan melihat pengaruh kerapatan mesh terhadap perubahan laju erosi. Tabel 2 menunjukkan parameter yang digunakan untuk validasi mesh.

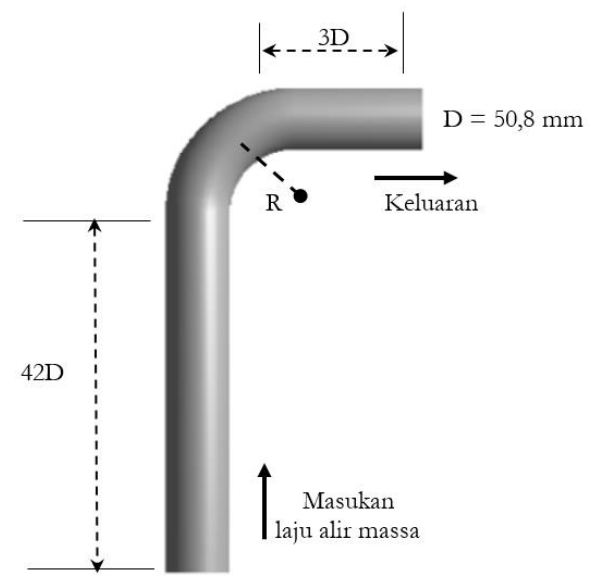

Gambar 1. Domain komputasi 
Tabel 1. Pengaturan grid penampang pipa

\begin{tabular}{|c|c|c|c|c|}
\hline Section & Mesh 1 & Mesh 2 & Mesh 3 & Mesh 4 \\
\hline $\mathrm{X}$ & 8 & 12 & 14 & 16 \\
\hline $\mathrm{Y}$ & 4 & 6 & 7 & 8 \\
\hline
\end{tabular}

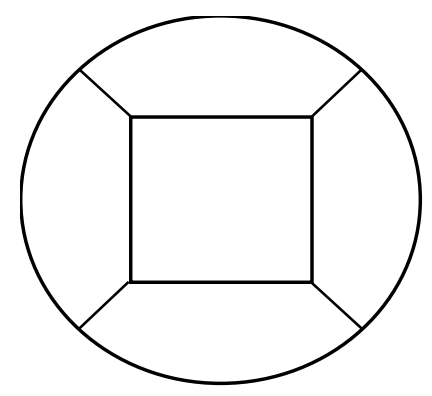

Gambar 2. Metode meshing penampang pipa

Tabel 2. Parameter validasi mesh

Parameter

Fluida
Kecepatan $(\mathrm{m} / \mathrm{s})$
Laju alir massa cairan $(\mathrm{kg} / \mathrm{s})$
Laju alir massa partikel $(\mathrm{kg} / \mathrm{s})$
Konsentrasi volume partikel $(\%)$

Air
6,3
12,7
0,1285
0,37

Air

6,

0,1285

0,37

\subsection{Kondisi Simulasi Aliran Multifasa Cair-Gas-Partikel}

Studi prediksi erosi aliran cair-gas-padat dalam belokan pipa ini menggunakan kerangka eulerian-lagrangian. Model eulerian digunakan untuk memecahkan persamaan aliran multifasa cairgas dan kerangka lagrangian dengan model fasa diskrit (Discrete Phase Model/DPM) digunakan untuk menentukan lintasan partikel abrasif dalam aliran dan tumbukannya dengan dinding pipa yang digunakan dalam perhitungan laju erosi.

Model yang digunakan untuk mensimulasikan aliran multifasa adalah eulerian mixture 2 fasa dengan cairan sebagai fasa primer dan gas sebagai fasa sekunder. Interaksi antar fasa dinyatakan dalam tegangan permukaan. Pasir sebagai fasa diskrit diasumsikan tidak mempengaruhi profil aliran fluida karena pembebanan partikel yang rendah (ANSYS Workbench Help).

Simulasi ini menggunakan model steady state dengan pertimbangan bahwa lintasan partikel didalam aliran dari masukan hingga keluaran sudah mencukupi untuk menghasilkan informasi paramater yang digunakan dalam perhitungan erosi. Slip velocity digunakan untuk mengakomodasi perbedaan kecepatan antara fasa kontinyu dan fasa terdispersi. Implicit body formulation diterapkan untuk memperbaiki konvergensi solusi dengan memperhitungkan kesetimbangan gradien tekanan dan body force (gravitasi dan tegangan permukaan) dalam persamaan momentum. Model viscous $k$ - $\varepsilon$ realizable dengan enhanced wall treatment digunakan untuk memperhitungkan faktor turbulensi didalam aliran dan mengangani viskositas didaerah dekat dinding (near-wall region). 
Metode solusi yang diterapkan dalam simulasi menggunakan scheme SIMPLE, gradient menggunakan Least Square Cell Based, tekanan menggunakan PRESTO!, momentum dan volume fraction menggunakan QUICK, turbulence kinetic energy dan dissipation rate keduanya menggunakan Second Order Upwind untuk memperkecil galat perhitungan (ANSYS Workbench Help).

Untuk menentukan besaran dan profil erosi pada material target, ANSYS Fluent 18.2 menyediakan beberapa model erosi yang bisa digunakan, yaitu model Generic, Finnie, McLaury dan Oka. Fitur ini dapat ditemukan dengan mengaktifkan Erosion/Accretion didalam tab Physical Models setelah Discrete Phase Model diaktifkan pada tahap setup model. Pada studi ini, model erosi yang digunakan adalah Finnie, McLaury dan Oka. Parameter fluida, partikel dan material target yang dimasukkan ke dalam Fluent untuk keperluan validasi diperoleh berdasarkan informasi yang ditunjukkan pada Tabel 3. Adapun pada simulasi lanjutan untuk melihat pengaruh perubahan parameter fluida, partikel dan ukuran pipa terhadap laju dan profil erosi menggunakan data yang ditunjukkan pada Tabel 2 dan 3.

\subsection{Pemodelan Aliran Fluida}

Persamaan kontinuitas untuk campuran adalah:

$$
\frac{\partial}{\partial t}\left(\rho_{m}\right)+\nabla \cdot\left(\rho_{m} \vec{v}_{m}\right)=\dot{m}
$$

Dimana $\vec{v}_{m}$ adalah rata-rata kecepatan massa.

$$
\vec{v}_{m}=\frac{\sum_{k=1}^{n} \alpha_{k} \rho_{k} v_{k}^{\prime}}{\rho_{m}}
$$

Dengan $\rho_{m}$ adalah kerapatan campuran.

$$
\rho_{m}=\sum_{k=1}^{n} \alpha_{k} \rho_{k}
$$

$\alpha_{k}$ adalah fraksi volume fasa $k$ dan $\dot{m}$ mengGambarkan perpindahan massa.

Persamaan momentum untuk campuran diperoleh dengan menjumlahkan persamaan momentum tiap fasa.

$$
\begin{gathered}
\frac{\partial}{\partial t}\left(\rho_{m} \vec{v}_{m}\right)+\nabla \cdot\left(\rho_{m} \vec{v}_{m} \vec{v}_{m}\right) \\
=-\nabla p+\nabla \cdot\left[\mu_{m}\left(\nabla \vec{v}_{m}+\nabla \vec{v}_{m}^{T}\right)\right]+\rho_{m} \vec{g}+\vec{F}+\nabla \cdot\left(\sum_{k=1}^{n} \alpha_{k} \rho_{k} \vec{v}_{d r, k} \vec{v}_{d r, k}\right)
\end{gathered}
$$

Dengan $n$ adalah banyaknya fasa, $\vec{F}$ adalah body force, $\mu_{m}$ adalah viskositas campuran dengan formula:

$$
\mu_{m}=\sum_{k=1}^{n} \alpha_{k} \mu_{k}
$$

$\vec{v}_{d r, k}$ adalah kecepatan drift untuk fasa sekunder k dengan formula:

$$
\vec{v}_{d r, k}=\vec{v}_{k}-\vec{v}_{m}
$$

Persamaan perpindahan untuk $k$ dan $\varepsilon$ pada model $k-\varepsilon$ adalah:

dan

$$
\frac{\partial}{\partial t}(\rho k)+\frac{\partial}{\partial x_{i}}\left(\rho k u_{j}\right)=\frac{\partial}{\partial x_{i}}\left[\left(\mu+\frac{\mu_{t}}{\sigma_{k}}\right) \frac{\partial k}{\partial x_{j}}\right]+G_{k}+G_{b}-\rho \varepsilon-Y_{M}+S_{k}
$$

$$
\frac{\partial}{\partial t}(\rho \varepsilon)+\frac{\partial}{\partial x_{i}}\left(\rho \varepsilon u_{j}\right)=\frac{\partial}{\partial x_{j}}\left[\left(\mu+\frac{\mu_{t}}{\sigma_{\varepsilon}}\right) \frac{\partial \varepsilon}{\partial x_{j}}\right]+\rho C_{1} S \varepsilon-\rho C_{2} \frac{\varepsilon^{2}}{k+\sqrt{v \varepsilon}}+C_{1 \varepsilon} \frac{\varepsilon}{k} C_{3 \varepsilon} G_{b}+S_{\varepsilon}
$$


dimana:

$$
C_{1}=\max \left[0.43, \frac{\eta}{\eta+5}\right]
$$

dan

$$
\eta=S \frac{k}{\varepsilon}
$$

dengan:

$G_{k} \quad=$ energi kinetik turbulen karena gradien kecepatan rata-rata.

$G_{b} \quad=$ energi kinetik turbulen karena buoyancy.

$Y_{M} \quad=$ energi akibat fluktuasi dilatasi dalam turbulen compressible pada keseluruhan laju disipasi.

$C_{2}, C_{1 \varepsilon}=$ konstanta.

$\sigma_{k}, \sigma_{\varepsilon} \quad=$ bilangan Prandtl turbulen untuk k dan $\varepsilon$.

$S_{k}, S_{\varepsilon} \quad=$ parameter yang bisa didefinisikan pengguna (user-defined).

\subsection{Pemodelan Gerak Partikel}

Prediksi lintasan partikel fasa diskrit yang digunakan oleh ANSYS Fluent diperoleh dengan mengintegralkan gaya kesetimbangan (force balance) partikel yang dituliskan dalam kerangka lagrangian. Persamaan gaya kestimbangan yang menunjukkan inersia partikel akibat gaya yang bekerja pada partikel yang jika dituliskan pada koordinat-x adalah:

$$
\frac{d u_{p}}{d t}=F_{D}\left(u-u_{p}\right)+\frac{g_{x}\left(\rho_{p}-\rho\right)}{\rho_{p}}+F_{x}
$$

dimana $F_{D}\left(u-u_{p}\right)$ adalah gaya drag per unit massa partikel.

$$
F_{D}=\frac{18 \mu}{\rho_{p} d_{p}^{2}} \frac{C_{D} R e}{24}
$$

dengan $u$ adalah kecepatan fasa fluida, $u_{p}$ adalah kecepatan partikel, $\mu$ adalah viskositas molekular fluida, $\rho$ adalah kerapatan fluida, $\rho_{p}$ adalah kerapatan partikel dan $d_{p}$ adalah diameter partikel. $R e$ adalah bilangan Reynolds relatif yang didefinisikan sebagai:

$$
R e \equiv \frac{\rho d_{p}\left|u_{p}-u\right|}{\mu}
$$

Haider dan Levenspiel [6] mengajukan persamaan koefisien drag yang memperhitungkan faktor bentuk partikel $(\phi)$, melalui persamaan:

dimana:

$$
C_{D}=\frac{24}{R e}\left(1+b_{1} R e^{b_{2}}\right)+\frac{b_{3} R e}{b_{4}+R e}
$$

$b_{1}=\exp \left(2,3288-6,4581 \emptyset+2,4486 \emptyset^{2}\right)$

$b_{2}=0,0964+0,5565 \emptyset$

$b_{3}=\exp \left(4,905-13,8944 \emptyset+18,4222 \emptyset^{2}-10,2599 \emptyset^{3}\right)$

$b_{4}=\exp \left(1,4681+12,2584 \emptyset-20,7322 \emptyset^{2}+15,8855 \emptyset^{3}\right)$

Faktor bentuk $(\varnothing)$ didefinisikan sebagai:

$$
\varnothing=\frac{S}{S}
$$

dimana s adalah luas permukaan bulatan yang memiliki volume yang sama dengan partikel, dan $\mathrm{S}$ adalah luas permukaan partikel yang sebenarnya. 
Persamaan lintasan dan persamaan tambahan yang mengGambarkan perpindahan massa atau panas dari dan ke partikel dipecahkan mengintegralkan secara bertahap terhadap waktu diskrit. Jika persamaan (11) diintegralkan terhadap waktu menghasilkan kecepatan partikel ditiap titik sepanjang lintasan dengan lintasan sendiri yang diprediksi sebagai:

$$
\frac{d x}{d t}=u_{p}
$$

Jika diasumsikan gaya yang bekerja pada partikel adalah konstan, maka persamaan lintasan dapat dituliskan dalam bentuk yang lebih sederhana:

dimana $\tau_{p}$ adalah waktu relaksasi partikel.

$$
\frac{d u_{p}}{d t}=\frac{1}{\tau_{p}}\left(u-u_{p}\right)
$$

Fluent menggunakan trapezoidal scheme untuk mengintegralkan persamaan (17):

dimana n menunjukkan banyaknya iterasi, dan

$$
\frac{u_{p}^{n+1}-u_{p}^{n}}{\Delta t}=\frac{1}{\tau}\left(u^{*}-u_{p}^{n+1}\right)+\cdots
$$

$$
\begin{aligned}
u^{*} & =\frac{1}{2}\left(u^{n}+u^{n+1}\right) \\
u^{n+1} & =u^{n}+\Delta t u_{p}^{n} \cdot \nabla u^{n}
\end{aligned}
$$

Persamaan (16) dan (17) dipecahkan secara simultan untuk menentukan kecepatan dan posisi partikel terhadap waktu.

\subsection{Model Erosi}

\subsubsection{Model Erosi Finnie}

Berdasarkan beberapa asumsi, Finnie mengajukan dua persamaan untuk memperkirakan volume material yang hilang oleh butiran abrasif tunggal untuk sudut tumbukan rendah dan tinggi sebagai berikut:

$$
\begin{gathered}
\varepsilon_{V P}=\frac{m_{p} V_{p}^{2}}{p \psi \kappa}\left(\sin (2 \alpha)-\frac{6}{\kappa} \sin ^{2}(\alpha)\right) \text { untuk } \tan \alpha \leq \frac{\kappa}{6} \\
\varepsilon_{V P}=\frac{m_{p} V_{p}^{2}}{p \psi \kappa}\left(\frac{\kappa \cos ^{2} \alpha}{6}\right) \quad \text { untuk } \tan \alpha \geq \frac{\kappa}{6}
\end{gathered}
$$

Dimana $\varepsilon_{V P}$ adalah volume material permukaan yang dipindahkan, $m_{p}$ adalah massa partikel, $V p$ adalah kecepatan partikel, $\mathrm{p}$ adalah konstanta tegangan aliran plastis, $\alpha$ adalah sudut tumbukan partikel, $\kappa$ adalah rasio komponen gaya vertikal pada permukaan partikel terhadap komponen gaya horizontal. $\psi$ adalah rasio kedalaman kontak 1 terhadap $y_{t}$ (sesuai Gambar 3) memiliki nilai konstan, Finnie menggunakan nilai 2 untuk parameter ini. Persamaan pertama berlaku untuk sudut tumbukan rendah yang berkaitan dengan keadaan dimana partikel meninggalkan permukaan sambil memotong. Persamaan kedua berlaku untuk sudut tumbukan tinggi pada keadaan dimana gerak horizontal ujung partikel terhenti saat memotong. 


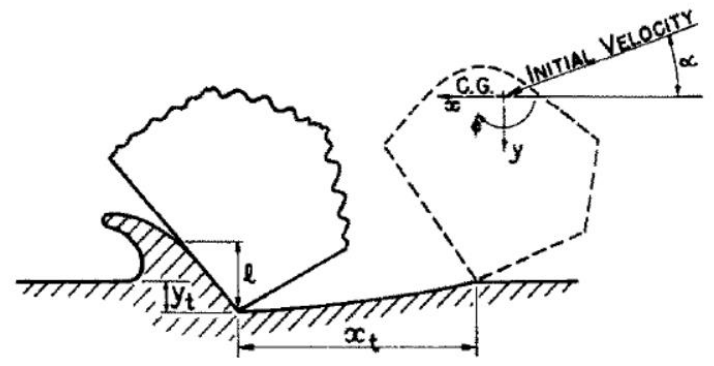

Gambar 3. Abrasif yang menumbuk permukaan dan memotong material. Vektor kecepatan awal membentuk sudut $\alpha$ terhadap pusat gravitasi partikel (Finnie, 1960).

\subsubsection{Model Erosi McLaury}

McLaury mengajukan model prediksi laju erosi partikel dengan fluida pembawa air. Model ini dikembangkan untuk mensimulasikan laju erosi pada aliran cair-padat (slurry). Model McLaury dituliskan sebagai berikut (Oka et al, 2005).

$$
\begin{gathered}
E=A V^{n} f(\gamma) \\
A=F B h^{k}
\end{gathered}
$$

\section{Dimana:}

$F \quad=$ konstanta empiris

$V \quad=$ kecepatan tumbukan partikel

Bh = angka kekerasan Brinell material dinding

$k=-0,59$ untuk carbon steel (nilai $k$ berbeda untuk material lain)

dengan:

$$
\begin{gathered}
f(\gamma)=b \gamma^{2}+c \gamma \quad \text { untuk } \gamma \leq \gamma_{\text {lim }} \\
f(\gamma)=x \cos ^{2} \gamma \sin (w \gamma)+y \sin ^{2}(\gamma)+z \quad \text { untuk } \gamma>\gamma_{\text {lim }}
\end{gathered}
$$

Nilai konstanta b, c, w, x dan y pada model diatas ditentukan berdasarkan eksperimen. Nilai z ditentukan sedemikian sehingga kedua persamaan fungsi sudut diatas berdekatan pada $\gamma=\gamma_{\text {lim }}$, dengan $\gamma_{\text {lim }}$ adalah sudut transisi.

\subsubsection{Model Erosi Oka}

Model erosi Oka dikembangkan berdasarkan pengujian yang dilakukan pada beberapa jenis material target seperti besi murni, aluminum, baja karbon dan baja stainless. Laju erosi akibat tumbukan partikel dengan material target pada sudut tumbukan $\alpha$ dinyatakan sebagai (Oka et al, 2005; $\quad$ Sedrez et al, 2019):

$$
E(\alpha)=g(\alpha) E_{90}
$$

$E_{90}$ adalah laju erosi pada sudut tumbukan $90^{\circ}$ dan $g(\alpha)$ adalah fungsi sudut tumbukan yang dinormalkan, dinyatakan oleh dua fungsi trigonometri dan angka kekerasan awal material $H v$ (dalam GPa), sesuai persamaan berikut:

$$
g(\alpha)=(\sin \alpha)^{n 1}(1+H v(1-\sin \alpha))^{n 2}
$$

$n 1$ dan $n 2$ adalah eksponen yang ditentukan oleh kekerasan material dan kondisi tumbukan lainnya seperti properti partikel termasuk bentuk partikel. $g(\alpha)$ ditentukan berdasarkan (Oka et al, 2005) Representasi grafis $g(\alpha)$ ditunjukkan seperti Gambar 4. 


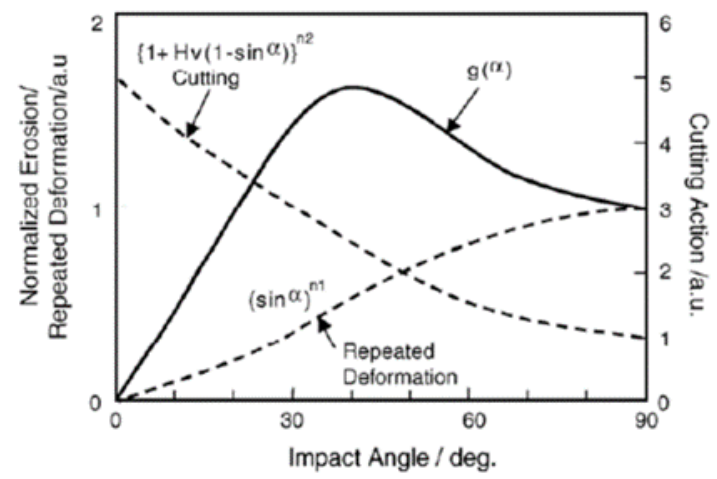

Gambar 4. Konsep erosi akibat deformasi plastis berulang dan pemotongan [9].

Suku pertama dari persamaan (28) mengGambarkan deformasi plastis berulang atau karakteristik getas dan dengan komponen vertikal dari energi tumbukan partikel jika $n 1=2$. Suku kedua menunjukkan fenomena pemotongan, dimana erosi relatif dan lebih efektif terjadi pada sudut tumbukan yang lebih rendah. $E_{90}$ dinyatakan sebagai:

$$
E_{90}=K(H v)^{k 1}(v)^{k 2}(D)^{k 3}
$$

dimana k1, k.2 dan k.3 adalah faktor eksponen yang dipengaruhi oleh parameter lain. $K$ adalah sembarang unit yang menunjukkan properti partikel seperti bentuk dan tingkat kekerasan, yang nilainya berbeda-beda untuk jenis partikel berbeda. ANSYS Fluent sudah memasukkan nilai konstanta-konstanta empiris tersebut ke dalam masing-masing model erosi, sehingga pengguna hanya memasukkan parameter fluida, partikel dan material target.

\subsection{Prosedur Simulasi}

Secara garis besar langkah-langkah simulasi dalam studi ini secara adalah:

a. Membuat geometri sebagai domain komputasi.

b. Melakukan studi kualitas mesh.

c. Pemodelan aliran multifasa dan model fasa diskrit sesuai dengan kondisi eksperimen.

d. Validasi simulasi berdasarkan hasil eksperimen.

e. Variasi parameter aliran fluida dan partikel.

Geometri komputasi yang digunakan untuk validasi simulasi ini berdasarkan eksperimen yang dilakukan oleh Sedrez seperti ditunjukkan pada Gambar 1, dengan kondisi eksperimen sesuai data yang ditunjukkan pada Tabel 3. Eksperimen yang dilakukan Sedrez menghasilkan laju erosi $0,12,0,18,0,26$ dan $0,40 \mathrm{~mm} /$ day untuk masing-masing kasus 1, 2, 3 dan 4. 
H. J. Atmaja et al. / Journal of Mechanical Design and Testing 2(1), (2020), 47-65

Tabel 3. Kondisi eksperimen Sedrez (Sedrez, 2019)

\begin{tabular}{|l|l|c|c|c|}
\hline Diatemer partikel $(\mu \mathrm{m})$ & \multicolumn{4}{l|}{300} \\
\hline Kerapatan partikel $\left(\mathrm{kg} / \mathrm{m}^{3}\right)$ & 2650 & Kasus 3 & Kasus 4 \\
\hline Kerapatan material pipa $\left(\mathrm{kg} / \mathrm{m}^{3}\right)$ & 7800 & Kasus 1 & Kasus 2 & air \\
\hline Parameter & air & air dan udara & air dan udara & air dan udara \\
\hline Fluida & 6,3 & 6 dan 2,4 & 5,5 dan 3,76 & 6,31 dan 5,46 \\
\hline Kecepatan $(\mathrm{m} / \mathrm{s})$ & 12,7 & 12,1 dan & 11,2 dan & 12,8 dan \\
\hline Laju alir massa cairan dan gas $(\mathrm{kg} / \mathrm{s})$ & & 0,00505 & 0,00933 & 0,01356 \\
\hline Laju alir massa partikel $(\mathrm{kg} / \mathrm{s})$ & 0,1285 & 0,1150 & 0,0914 & 0,1131 \\
\hline Konsentrasi volume partikel $(\%)$ & 0,37 & 0,36 & 0,31 & 0,33 \\
\hline
\end{tabular}

\section{HASIL DAN PEMBAHASAN}

\subsection{Validasi Mesh dan Validasi Simulasi}

Dengan menggunakan prosedur pengaturan mesh sesuai Tabel 1 dan parameter sesuai Tabel 2 diperoleh hasil seperti ditunjukkan pada Gambar 5. Dari Gambar 5 terlihat bahwa deviasi laju erosi maksimum (ER) antara mesh 4 dan 3 sudah sangat kecil, yaitu 2,2\%, 0,4\% dan 8,3\% masing-masing untuk model Finnie, McLaury dan Oka. Deviasi antara mesh 4 dan 2 untuk model Finnie, McLaury dan Oka masing-masing adalah 20\%, 15,9\% dan 24,9\%. Mesh 2 dapat digunakan untuk simulasi berikutnya dengan pertimbangan bahwa perbedaan $20 \%$ bisa diterima untuk simulasi prediksi erosi (Fluent 6.0 User's Guide, 2001).

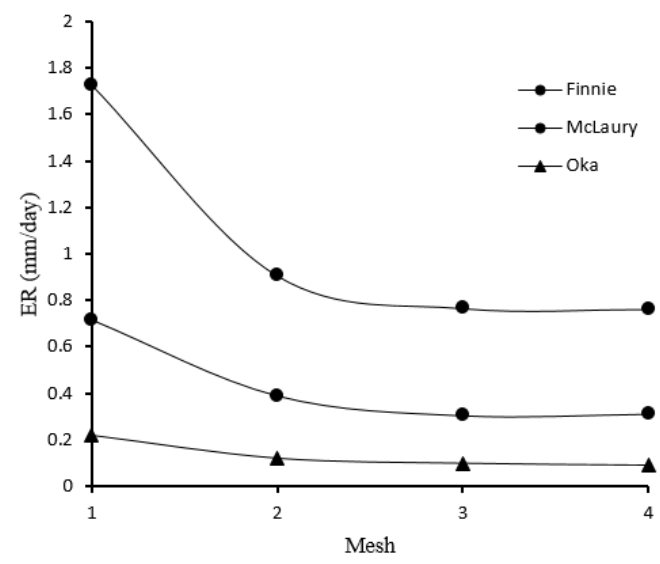

Gambar 5. Grafik uji mesh independency

Hasil validasi simulasi ditunjukkan pada Tabel 4 dengan representasi grafis ditunjukkan pada Gambar 5. Terlihat bahwa bahwa model erosi Oka lebih mendekati hasil eksperimen dengan perbedaan relatif $0,3 \%$ pada kasus 1 dan $0,8 \%$ pada kasus 4 . Perbedaan relatif terbesar $24 \%$ pada kasus 2, diikuti perbedaan relatif 21,6\% pada kasus 3. Model Finnie dan McLaury memberikan perbedaan relatif yang cukup besar pada semua kasus yaitu lebih dari $100 \%$ seperti ditunjukkan pada Tabel 4. Namun demikian terlihat bahwa pada dasarnya ketiga model erosi tersebut menunjukkan kecenderungan hasil yang hampir sama. Kecenderungan yang sama pada 
model Finnie, McLaury dan Oka menunjukkan bahwa ketiga model memiliki pendekatan yang sama dalam menentukan parameter yang mempengaruhi erosi. Ketiganya menggunakan kecepatan partikel, fungsi sudut dan konstanta yang tergantung dari tingkat kekerasan material baja karbon dalam dasar pemodelannya.

Tabel 4. Perbandingan simulasi model erosi dengan hasil eksperimen

\begin{tabular}{llllc}
\hline \multirow{2}{*}{ Kasus } & \multicolumn{4}{c}{ ER $(\mathbf{m m} /$ day) } \\
\cline { 2 - 5 } & Finnie & McLaury & Oka & Eksperimen \\
\hline Kasus 1 & 0,3910 & 0,9072 & 0,1196 & 0,12 \\
\hline Kasus 2 & 0,4187 & 0,9249 & 0,1362 & 0,18 \\
\hline Kasus 3 & 0,5782 & 1,2406 & 0,2038 & 0,26 \\
\hline Kasus 4 & 1,0889 & 2,2043 & 0,4032 & 0,40 \\
\hline
\end{tabular}

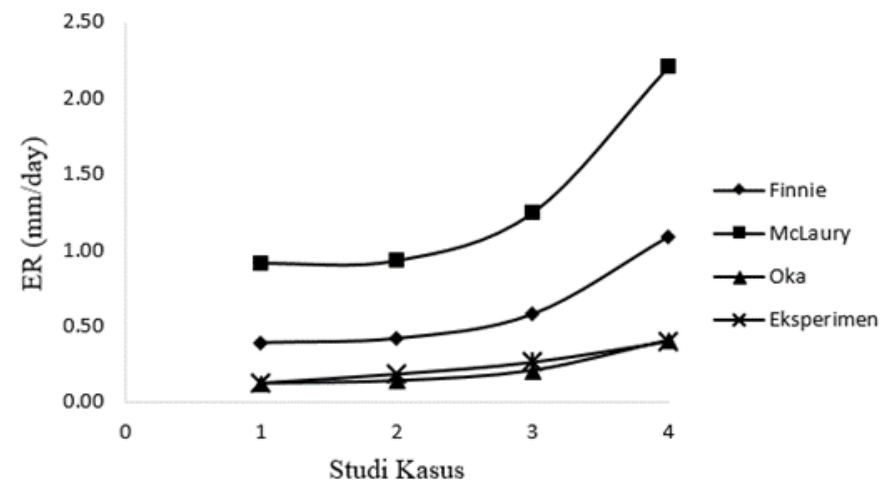

Gambar 3.2. Perbandingan hasil simulasi dan eksperimen

Setelah simulasi sudah divalidasi maka variasi dilakukan untuk melihat pengaruh perubahan parameter fluida dan partikel terhadap laju erosi maksimum dan profil erosi yang terjadi. Simulasi menggunakan fluida minyak mentah, gas alam dan partikel pasir dengan parameter sebagaimana ditunjukkan pada Tabel 5. Skenario variasi yang dilakukan pada studi ini ditunjukkan pada Tabel 6.

Tabel 5. Parameter fluida dan partikel dalam simulasi

\begin{tabular}{lccc}
\hline Fluida & $\begin{array}{c}\text { Kerapatan } \\
(\mathbf{k g} / \mathbf{m} 3)\end{array}$ & $\begin{array}{c}\text { Viskositas } \\
(\mathbf{k g} / \mathbf{m}-\mathbf{s})\end{array}$ & $\begin{array}{c}\text { Tegangan } \\
\text { Permukaan }(\mathbf{N} / \mathbf{m})\end{array}$ \\
\cline { 1 - 3 } Minyak hidrokarbon & 879,6 & $3,839 \times 10-3$ & - \\
\hline Air & 998,2 & $1,003 \times 10-3$ & - \\
\hline Gas Alam & 0,762 & $1,300 \times 10-5$ & 0.072 \\
$\begin{array}{l}\text { Minyak mentah } \\
\text { water cut } \mathbf{9 0 \%}\end{array}$ & 986,34 & $1,287 \times 10-3$ & \\
\hline & & & \\
\hline Partikel & & & \\
\hline Diameter & $30-300 \mu \mathrm{m}$ & & \\
\hline Kerapatan & $2.224 \mathrm{~kg} / \mathrm{m}^{3}$ & & \\
\hline
\end{tabular}


H. J. Atmaja et al. / Journal of Mechanical Design and Testing 2(1), (2020), 47-65

Tabel 6. Skenario variasi parameter dalam simulasi

\begin{tabular}{llc}
\hline \multicolumn{1}{c}{ Parameter } & \multicolumn{1}{c}{ Data Masukan } & \multicolumn{1}{c}{ Setara } \\
\hline Diameter pipa (mm) & 50,$8 ; 76,2 ; 101,16$ & $(2,3$ dan 4 inch $)$ \\
\hline $\begin{array}{l}\text { Laju alir minyak mentah } \\
\text { (kg/s) }\end{array}$ & $7,260-14,520$ & $(4000-8000 \mathrm{bbls} /$ day $)$ \\
\hline Laju alir gas (kg/s) & $0,0025-0,075$ & $(0,1-1 \mathrm{MMSCFD})$ \\
\hline Laju alir partikel (kg/s) & $0,000926-0,001852$ & $\begin{array}{c}\mathbf{2 . 6 0 .} \\
\text { kg/day) }\end{array}$ \\
\hline
\end{tabular}

\subsection{Pengaruh Laju Alir Massa Minyak Mentah Terhadap Laju Erosi}

Pada diameter pipa tetap dengan laju alir gas dan diameter partikel tetap, laju erosi maksimum meningkat dengan kenaikan laju alir minyak mentah seperti ditunjukkan pada Gambar 6.

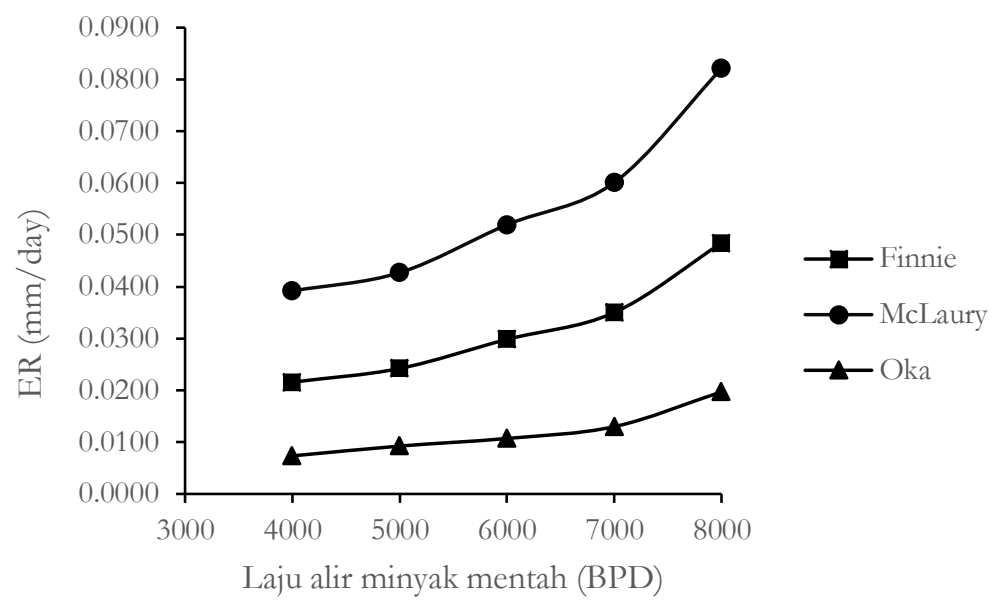

Gambar 6. Pengaruh laju alir minyak mentah terhadap laju erosi

Dari hasil simulasi dapat dilihat bahwa laju erosi maksimum meningkat dengan kenaikan laju alir minyak mentah. Keempat model menunjukkan kecenderungan yang sama. Sebagaimana hasil yang diperoleh pada tahap validasi, model erosi Oka memberikan hasil yang paling kecil dibandingkan dua model lainnya, sementara model McLaury memberikan hasil laju erosi yang paling besar. Hasil ini sesuai dengan teori bahwa laju erosi berbanding lurus dengan kecepatan. Dalam hal ini peningkatan laju alir fasa cair berarti peningkatan kecepatan aliran fluida yang pada akhirnya meningkatkan kecepatan partikel yang menumbuk dinding material target. Kondisi ini sesuai dengan hasil penelitian Zhang et al. yang menunjukkan bahwa laju erosi meningkat dengan kenaikan kecepatan fluida cair. Pada Gambar 7 terlihat bahwa erosi sebagian besar terdistribusi ke bagian luar belokan dengan kenaikan laju alir fasa cair. Hal ini menunjukkan bahwa fluida dengan kecepatan yang lebih tinggi bergerak dari inti (sumbu pipa vertikal) aliran ke arah punggung belokan. Studi eksperimental aliran dua fasa air-udara yang dilakukan Yadav menunjukkan bahwa fluida di daerah belokan mengalami gaya sentripetal yang mengarahkan aliran dari pusat ke bagian luar belokan. 


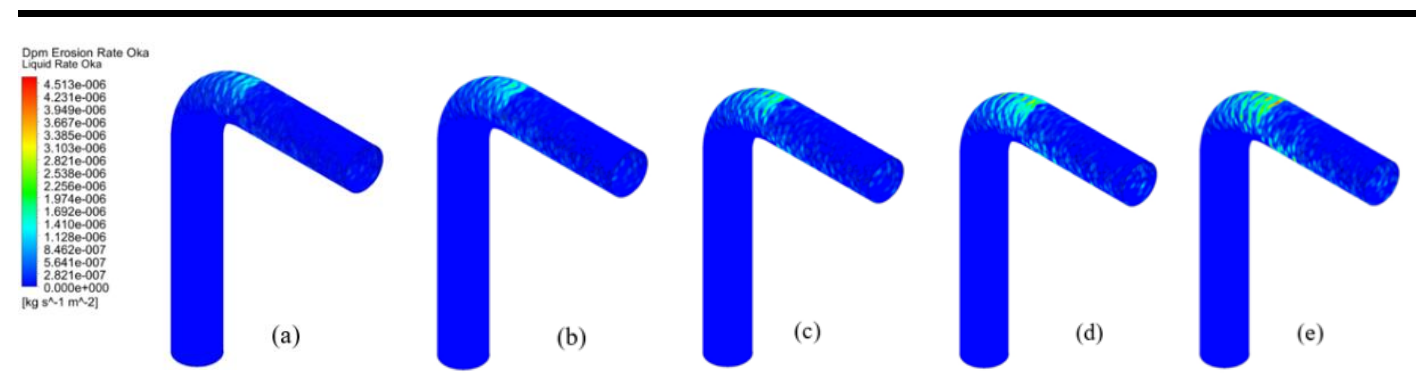

Gambar 7. Profil erosi pada laju alir fasa cair (a) $7,26 \mathrm{~kg} / \mathrm{s}$ (b) $9,075 \mathrm{~kg} / \mathrm{s}$ (c) $10,890 \mathrm{~kg} / \mathrm{s}$ (d) 12,705 $\mathrm{kg} / \mathrm{s}$ (e) $14,520 \mathrm{~kg} / \mathrm{s}$.

\subsection{Pengaruh Laju Alir Massa Gas Terhadap Laju Erosi}

Pada diameter pipa tetap dengan laju alir minyak mentah dan diameter partikel tetap, laju erosi maksimum meningkat dengan kenaikan laju alir gas seperti ditunjukkan pada Gambar 8. Hal ini disebabkan dengan meningkatnya laju alir gas maka kecepatan fluida semakin meningkat sesuai dengan penjumlahan kecepatan superfisial masing-masing fasa didalam fluida.

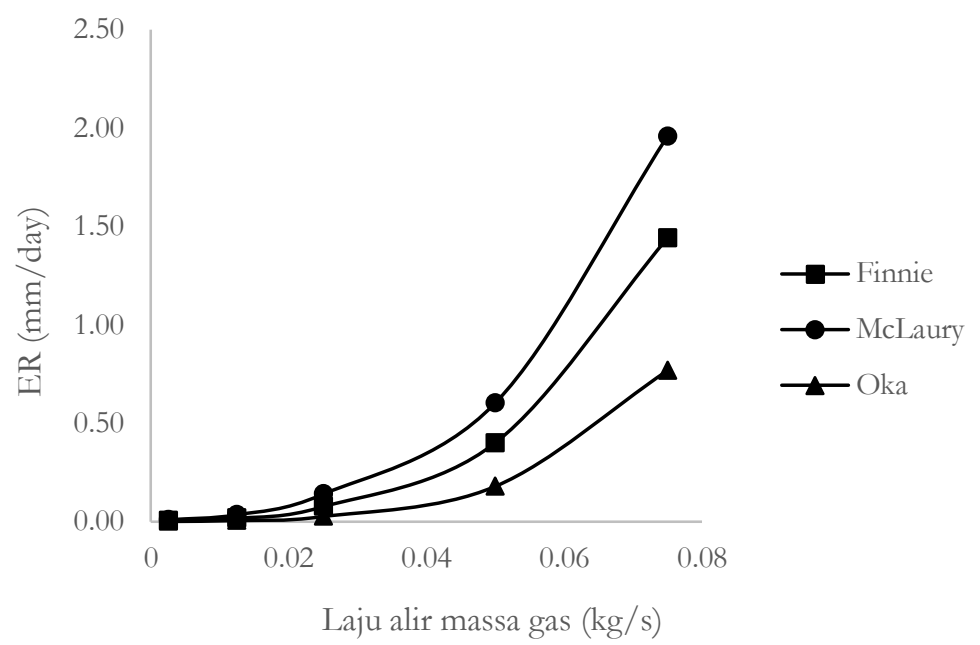

Gambar 8. Pengaruh laju alir fasa gas terhadap laju erosi

Dari Gambar 9 dapat dilihat bahwa pada laju alir gas rendah, erosi maksimum terjadi di belokan bagian samping dan semakin bergeser ke tengah seiring peningkatan laju alir gas. Disamping itu peningkatan aliran gas cenderung menyebabkan lebih banyak partikel yang menumbuk dinding pipa. Keadaan ini sesuai dengan penelitian yang dilakukan oleh Xu et al. bahwa kenaikan kecepatan gas menyebabkan kapasitas pengangkutan partikel oleh gas meningkat dan meningkatkan energi kinetik partikel sehingga tekanan sentuh lebih besar pada dinding dalam pipa. 


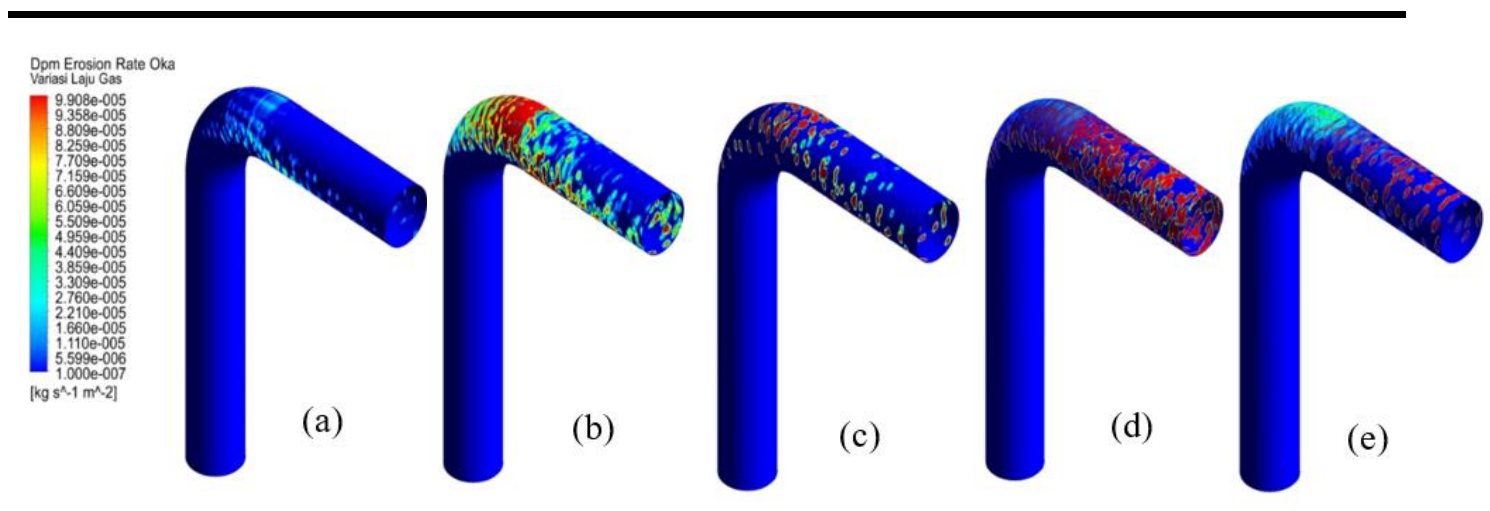

Gambar 9. Profil erosi pada laju alir gas (a) $0,0025 \mathrm{~kg} / \mathrm{s}$; (b) $0,0125 \mathrm{~kg} / \mathrm{s}$; (c) $0,025 \mathrm{~kg} / \mathrm{s}$;

(d) $0,05 \mathrm{~kg} / \mathrm{s} ;($ e) $0,075 \mathrm{~kg} / \mathrm{s}$.

Perbedaan besaran laju erosi maksimum antara ketiga model dengan kenaikan laju alir fluida dapat dilihat dari beberapa hal. Pertama adalah bagaimana perbedaan ketiga model dalam menentukan eksponen kecepatan, Finnie menggunakan nilai 2, McLaury menggunakan nilai nilai 1,73, sementara Oka meggunakan eksponen 0,19 . Hal ini yang memungkinkan laju Erosi yang dihasilkan oleh model Oka paling kecil dibandingkan model lainnya. Kedua, penentuan konstanta empiris pada ketiga model menggunakan pendekatan yang berbeda sesuai dengan kondisi eksperimen masing-masing model. Ketiga, acuan sudut tumbukan kritis yang digunakan ketiga model juga berbeda, Finnie mengambil sudut kritis pada 18,50, McLaury menggunakan sudut $15^{\circ}$, sementara Oka secara tidak langsung menunjukkan sudut sekitar $40^{\circ}$ sebagai sudut tumbukan maksimum, seperti ditunjukkan pada Gambar 4.

Dari grafik pengaruh laju alir fluida terhadap laju erosi maksimum, terlihat bahwa semakin tinggi laju alir (kecepatan) menghasilkan perbedaan relatif laju erosi maksimum yang semakin besar antar model erosi. Hal ini mengindikasikan bahwa penerapan model erosi dalam suatu simulasi sangat bergantung kepada rentang kecepatan aliran yang digunakan.

\subsection{Pengaruh Diameter Pipa Terhadap Laju Erosi}

Hasil simulasi dengan variasi diameter pipa ditunjukkan pada Gambar 10. Dari Gambar tersebut dapat dilihat bahwa semakin besar diameter pipa maka semakin kecil laju erosi yang terjadi. Hal ini disebabkan dengan bertambahnya diameter pipa maka kecepatan aliran fluida semakin rendah dan laju erosi semakin rendah sebanding dengan eksponen kecepatan masingmasing model. Xu et al. mengobservasi dari penelitiannya bahwa kenaikan diamater pipa meningkatkan dispersi partikel sehingga tumbukan partikel pada dinding dalam pipa juga terdispersi, dengan demikian laju erosi maksimum menurun. 


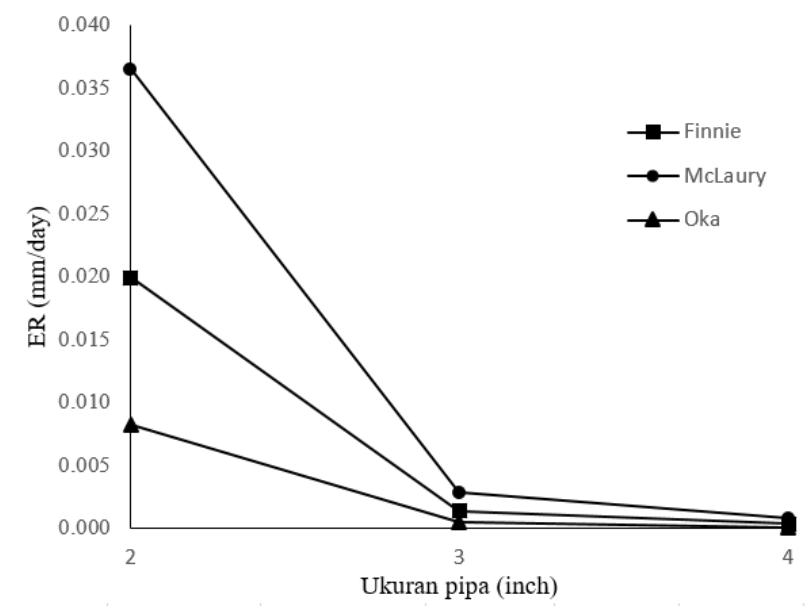

Gambar 10. Pengaruh diameter pipa terhadap laju erosi
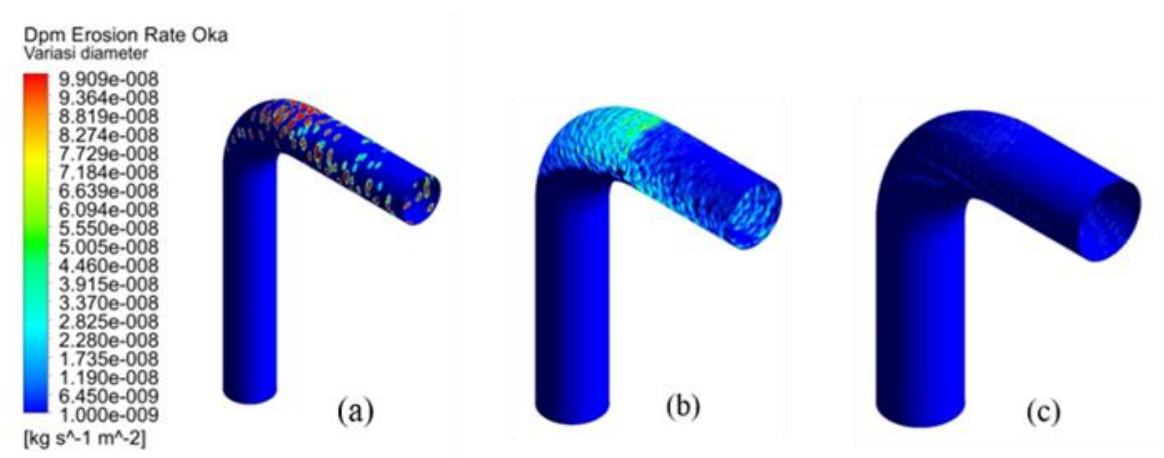

Gambar 11. Profil erosi pada pipa diameter (a) 2 inch (b) 3 inch (c) 4 inch.

Gambar 11 menunjukkan bahwa distribusi erosi pada pipa 2 inch hampir sama dengan pipa 3 inch yaitu terdistribusi dominan pada punggung belokan, yang membedakan adalah pada besaran laju erosi. Pada pipa berdiameter 4 inch selain menurunnya laju erosi, profil erosi tidak lagi pada punggung belokan melainkan bergeser ke bawah. Hal ini dimungkinkan dengan meningkatnya diameter pipa kecepatan aliran menurun sehingga gaya sentripetal yang menyebabkan aliran dari daerah inti mengarah ke dinding belokan bagian luar juga menurun. Penurunan dua kali kecepatan setara dengan penurunan empat kali gaya sentripetal fluida. Selain itu penurunan kecepatan menyebabkan bilangan Stokes menurun, artinya dominasi aliran fluida terhadap gerakan partikel tidak terlalu besar, sehingga inersia partikel cenderung mengarahkan partikel ke bawah.

\subsection{Pengaruh Laju Alir Massa Partikel Terhadap Laju Erosi}

Hasil simulasi variasi laju alir partikel abrasif ditunjukkan pada Gambar 12. Dari Gambar terlihat bahwa laju erosi bertambah dengan kenaikan laju alir massa partikel. Kondisi ini disebabkan dengan meningkatnya laju alir massa partikel maka semakin banyak partikel yang 
menumbuk dinding dalam pipa sehingga meningkatkan laju erosi. Fenomena peningkatan erosi akibat meningkatnya laju alir massa partikel memiliki kecenderungan yang sama dengan kenaikan laju alir fluida cair, sebagaimana ditunjukkan pada Gambar 6.

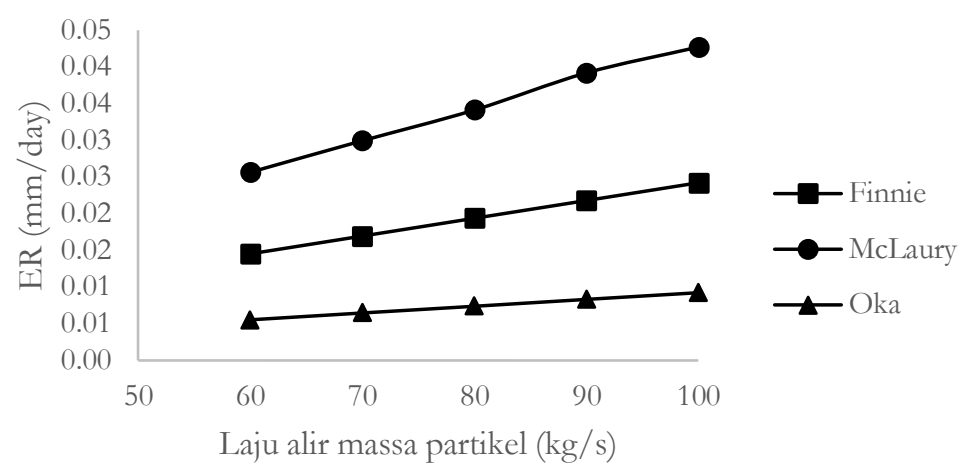

Gambar 12. Pengaruh laju alir partikel terhadap laju erosi

Gambar 13 memperlihatkan profil erosi dengan variasi laju alir massa fluida 60 - 100 $\mathrm{kg} /$ day. Pada laju alir partikel rendah, besaran laju erosi terlihat rendah dan distribusi erosi yang tidak terlalu banyak pada daerah punggung belokan. Laju erosi meningkat seiring dengan meningkatnya distribusi erosi didaerah punggung belokan ketika laju alir massa partikel mulai dari 70 hingga $100 \mathrm{~kg} /$ day dengan pola yang sama dengan profil erosi pada variasi laju alir fasa cair. Di dalam ANSYS Fluent, laju alir massa partikel digunakan untuk menentukan massa partikel yang kemudian akan dimasukkan kedalam perhitungan model erosi. Karena itu laju erosi dengan peningkatan massa partikel menghasilkan kenaikan yang linier, sedangkan peningkatan kecepatan fluida menghasilkan kecenderungan laju erosi yang naik secara eksponensial sesuai dengan konstanta eksponen yang digunakan didalam masing-masing model erosi.
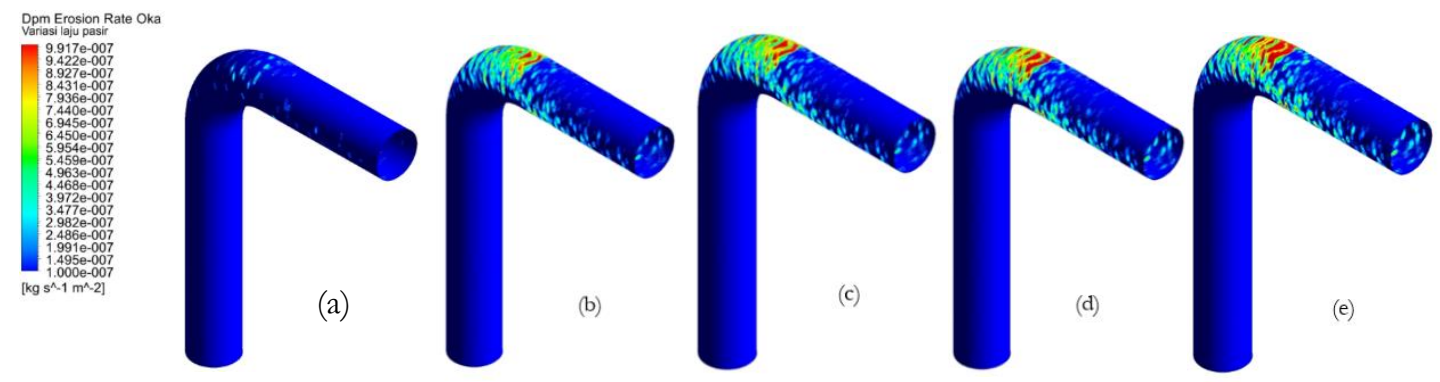

Gambar 13. Profil erosi pada laju alir partikel (a) $60 \mathrm{~kg} /$ day (b) $70 \mathrm{~kg} /$ day (c) $80 \mathrm{~kg} / \mathrm{day}$ (d) $90 \mathrm{~kg} / \mathrm{day}$ (e) $100 \mathrm{~kg} /$ day.

\subsection{Pengaruh Ukuran Partikel Terhadap Laju Erosi}

Hasil simulasi variasi ukuran partikel ditunjukkan pada Gambar 14. Dari Gambar tersebut terlihat bahwa laju erosi maksimum meningkat dengan semakin besarnya ukuran 
partikel. Hal ini sesuai dengan penelitian yang dilakukan Desale yang menyimpulkan bahwa peningkatan ukuran partikel menyebabkan meningkatnya laju erosi. Kenaikan diameter partikel berarti meningkatnya massa partikel, yang pada kecepatan tetap memberikan energi kinetik tumbukan terhadap material target lebih besar. Hasil simulasi juga didukung oleh hasil eksperimen yang dilakukan Okita yang menunjukkan bahwa semakin besar ukuran partikel cenderung meningkatkan rasio erosi pada sembarang nilai viskositas.

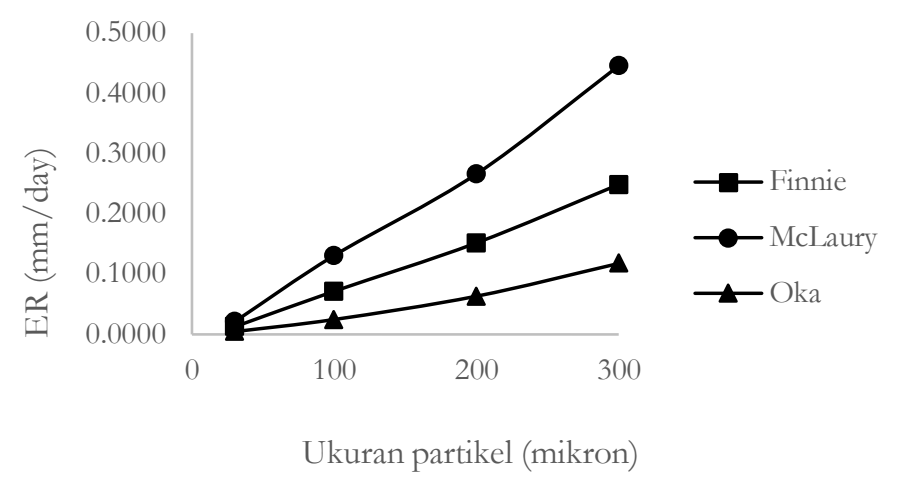

Gambar 14. Pengaruh ukuran partikel terhadap laju erosi.
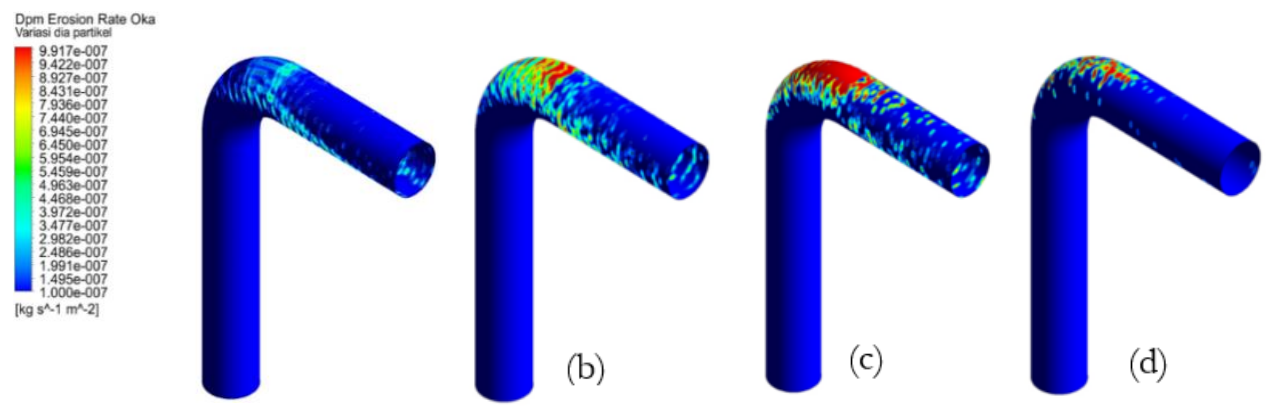

Gambar 15. Profil erosi pada variasi ukuran partikel

(a) $30 \mu \mathrm{m}$; (b) $100 \mu \mathrm{m}$; (c) $200 \mu \mathrm{m}$; (d) $300 \mu \mathrm{m}$.

Gambar 15 menunjukkan distribusi erosi yang hampir sama pada variasi diameter partikel 30 - $300 \mu \mathrm{m}$ dengan dominasi erosi terbesar pada daerah punggung belokan, yang membedakan adalah pada intensitas laju erosinya. Pada diameter $200 \mu \mathrm{m}$, terlihat konsentrasi laju erosi tinggi lebih padat dibandingkan pada diameter partikel $300 \mu \mathrm{m}$. Hal ini dimungkinkan bahwa pada partikel berdiameter lebih besar atau lebih berat, kecenderungan partikel untuk turun dari streamline fluida pembawa lebih besar. Peningkatan diamater partikel juga berarti meningkatkan bilangan Stokes yang berbanding lurus dengan kuadrat diameter partikel, sehingga kecenderungan partikel untuk tidak didominasi oleh aliran fluida semakin besar. Dapat dikatakan bahwa pada diameter partikel $300 \mu \mathrm{m}$, sebagian partikel terbawa oleh aliran fluida hingga menumbuk dinding dan sebagian lain keluar dari streamline fluida yang mengarah ke dinding pipa. 


\section{KESIMPULAN}

Pada studi ini prediksi erosi dengan menggunakan CFD dilakukan dengan menggunakan tiga model erosi yaitu model Finnie, McLaury dan Oka. Dari semua skenario simulasi yang dibuat, model McLaury menghasilkan laju erosi yang paling besar dibandingkan dua model lainnya. Model Oka secara konsisten menghasilkan laju erosi yang paling rendah. Perbedaan ini disebabkan ketiga model erosi dibangun dari pendekatan mekanistik maupun eksperimen yang berbeda, sehingga dimungkinkan masing-masing model erosi hanya berlaku pada kondisi tertentu saja. Dalam studi ini model Oka lebih unggul dibandingkan model Finnie dan McLaury dimana model Oka menghasilkan perbedaan relatif yang paling rendah terhadap eksperimen yang dijadikan acuan dalam validasi.

Hasil simulasi lanjutan menunjukkan bahwa laju erosi meningkat dengan peningkatan laju alir fasa cair, laju alir fasa gas, laju alir partikel, ukuran partikel dan laju erosi menurun dengan kenaikan diameter pipa.

Pada semua variasi laju alir fasa cair, profil erosi relatif sama yaitu kerapatan erosi terjadi pada punggung belokan akibat gaya sentripetal yang mengarahkan fluida dari inti pipa ke bagian luar belokan. Pada kenaikan laju alir gas, profil erosi terdistribusi di punggung belokan hingga bagian pipa keluaran yang disebabkan oleh peningkatan kapasitas pengangkutan partikel oleh fluida gas. Kenaikan ukuran pipa menyebabkan kecepatan aliran menurun dan gaya sentripetal menurun sehingga tumbukan partikel pada punggung belokan berkurang. Kenaikan laju alir partikel berarti peningkatan jumlah partikel yang menumbuk dinding pipa sehingga laju erosi meningkat. Lintasan partikel berdiameter kecil cenderung didominasi aliran fluida sehingga menghasilkan profil erosi terdistribusi pada bagian samping maupun punggung belokan sesuai dengan turbulensi didaerah belokan. Sementara semakin besar diameter partikel terdapat kecenderungan sebagian partikel keluar dari streamline fluida pembawa saat masuk ke daerah belokan karena dominasi fluida terhadap partikel semakin kecil (bilangan Stokes meningkat dengan kenaikan diameter partikel) sehingga semakin sedikit yang menumbuk punggung belokan. 


\section{DAFTAR PUSTAKA}

ANSYS Fluent 18.2. ANSYS Workbench Help.

Arabnejad H., A.Mansouri, S.A. Shirazi, B.S. McLaury, 2015, Evaluation of solid particle erosion equations and models for oil and gas industry applications, Journal Paper of SPE Annual Technical Conference and Exhibition. Society of Petroleum Engineers, SPE-174987-MS.

Chen X., B.S. McLaury, S.A. Shirazi, 2004, Application and Experimental Validation of a Computational Fluid Dynamics (CFD)-based Erosion Prediction Model in Elbows and Plugged-Tees, Journal of Computers \& Fluids, Vol. 33, pp. 1251-1272.

Desale, G.R., Gandhi, B.K., Jain, S.C, 2009, Particle Size Effects on The Slurry Erosion of Aluminum Alloy (AA 6063). Journal of Wear, Vol. 266, Page 1066-1071.

Edwards J.K. B.S McLaury, S.A. Shirazi, 2001, Modeling solid particle erosion in elbows and plugged tees. ASME Journal of Energy Resources Technology, Vol. 123, Page 277-284.

Finnie I, 1960, Erosion of Surface by Solid Particles, Journal of Wear, Vol. 3, Page 87-103.

Fluent 6.0 User's Guide, 2001.

Oka Y.I., K.Okamura, T.Yoshida, 2005, Practical estimation of erosion damage caused by solid particle impact Part 1: Effects of impact parameters on a predictive equation, Journal of Wear, Vol. 259, Page 95-101.

Oka Y.I., K.Okamura, T.Yoshida, 2005, Practical estimation of erosion damage caused by solid particle impact Part 2: Mechanical Properties of Materials Directly Associated with Erosion Damage, Journal of Wear, Vol. 259, Page 102-109.

Okita, R., Y. Zhang, B.S. McLaury, S.A. Shirazi, 2012, Experimental and Computational Investigation to Evaluate the Effect of Fluid Viscosity and Particle Size on Erosion Damage. Journal of Fluids Engineering, Vol. 134.

Parsi M., K. Najmi, F. Najafifard, S. Hassani, B.S. McLaury, S.A. Shirazi, 2014, A comprehensive review of solid particle erosion modeling for oil and gas wells and pipelines applications, Journal of Natural Gas Science and Engineering, Vol. 21, pp. 850-873.

Sedrez, T.A., S.A. Shirazi., Y.R. Rajkumar, K. Sambath, H.J. Subramani, 2019, Experiments and CFD Simulations of Erosion of a $90^{\circ}$ elbow in liquid-dominated liquid-solid and dispersed-bubble-solid flows. Journal of Wear, 426-427. Page 570-580.

Vieira, R.E., A. Mansouri, B.S. McLaury, S.A. Shirazi, 2016, Experimental and computational study of erosion in elbows due to sand particles in air flow, Journal of Powder Technology, Vol. 288, pp. 339-353.

Xu, J., Z. Lian, J. Hu, M. Luo, 2018, Prediction of Maximum Erosion Rate of Gas-Solid TwoPhase Flow Pipelines. Journal of Energies.

Yadav, M. S., 2013, Interfacial Area Transport Across Vertical Elbows in Air-Water Two Phase Flow, Dissertation, Department of Mechanical and Nuclear Engineering, The Pennsylvania State University.

Zhang, Y., E.P. Reuterfors, B.S. McLaury, S.A. Shirazi, E.F. Rybicki, 2007, Comparison of Computed and Measured Particle Velocities and Erosion in Water and Air Flows, Journal of Wear, Vol. 263, pp. 330-338. 